\title{
Glacier debris accumulation and sediment deformation influenced by permafrost: examples from Svalbard
}

\author{
B. Etzelmüller, J. O. Hagen, \\ Deparlment of Physical Geography, University of Oslo, P.O. Box 1042 Blindern, N-0316 Oslo, Norway \\ G. VATNE, \\ Department of Geography, University of Trondheim, N-7055 Draguoll, Nonway \\ R. S. ODEGARD, \\ The University Course on Svalbard, U.NIS, P.O. Box 156, N-9170 Longyearbyen, Norway \\ J. L. SOLLID \\ Department of Physical Geography, University of Oslo, P.O. Box 1042 Blindern, N-0316 Oslo, Norway
}

\begin{abstract}
The formation of ice-cored moraines and push moraines is discussed in the light of glacier thermal regime and glacier dynamics. Data from two Svalbard valley glaciers, Erikbreen and Usherbreen are presented. On Erikbreen, fossil forms were investigated, while on Usherbreen a surge ending in 1985 caused the formation of new push-moraine ridges. The push moraines are considered as a soil-mechanical problem. In a theoretical discussion the stress transmitted by the glaciers to the proglacial sediments is estimated. On Usherbreen, the compressive flow results in deformation both in old front ridges and in undisturbed frozen sediment layers in the front sandur. Thus, folding, thrust faulting and overriding all occur. Deformation of proglacial sediments seems to be highly dependent on the mechanical properties of the sediments. The sediments are strongly influenced by permafrost conditions. The unfrozen water content in the sediments governs the deformability, which in turn is partly determined by pore-water salinity. The distribution of push moraines in Svalbard is therefore restricted to areas below the Holocene marine limit, and they occur most frequently in areas of sedimentary bedrock. This study concludes that push moraines and ice-cored moraines require permafrost conditions. Push-moraine ridges are not formed in direct contact with the glacier, so they are geomorphologically not moraines, but deformed permafrost sediments. A model for glacier debris sedimentation and deformation is outlined for Svalbard glaciers ending on land.
\end{abstract}

\section{INTRODUCTION}

Two major types of moraine are found in front of glaciers in Svalbard. One is the ice-cored moraine, where an ice core is preserved by a layer of debris. The other is the push moraine, showing pushing and sediment thrusting due to an advancing ice front. Both types seem to be a function of the glacier thermal regime (cf. Boulton, 1970, 1972; Sollid and Sorbel, 1988) and the glacier dynamics. In this paper we will discuss some aspects of the genesis of moraines under permafrost conditions in Svalbard.

For most glaciers ending on land in Svalbard, an arc of ice-cored moraines, often up to $50 \mathrm{~m}$ in height, indicates the outermost postglacial position. Push moraines (Stauchendmoränen: Gripp, 1929) are small ridges, normally less than $10 \mathrm{~m}$ in height, forming the outermost part of moraine areas. These moraines may be defined as proglacial sediments, pushed and thrust to ridges by an advancing glacier. O. Liestol (personal communication, 1960) early recognised that push moraines in Svalbard were restricted to areas below the Holocene marine limit, and that salts of marine origin weakened the permafrost, allowing deformation of sediments. In this paper the name push moraines denotes composite ridges containing sediments with deformation structures not in direct contact with the glacier snout. This is in contrast to deformed sediments in reactivated ice-cored moraines.

Push moraines and ice-cored moraines coexist in front of some Svalbard glaciers. Glaciological and sedimentological analysis was carried out on two glaciers, Usherbreen and Erikbreen. The proglacial moraines on Erikbreen are fossil forms, generated during former advances (Fig. 1a). On Usherbreen active formation of push moraines was observed and measured during a surge in 1985. 


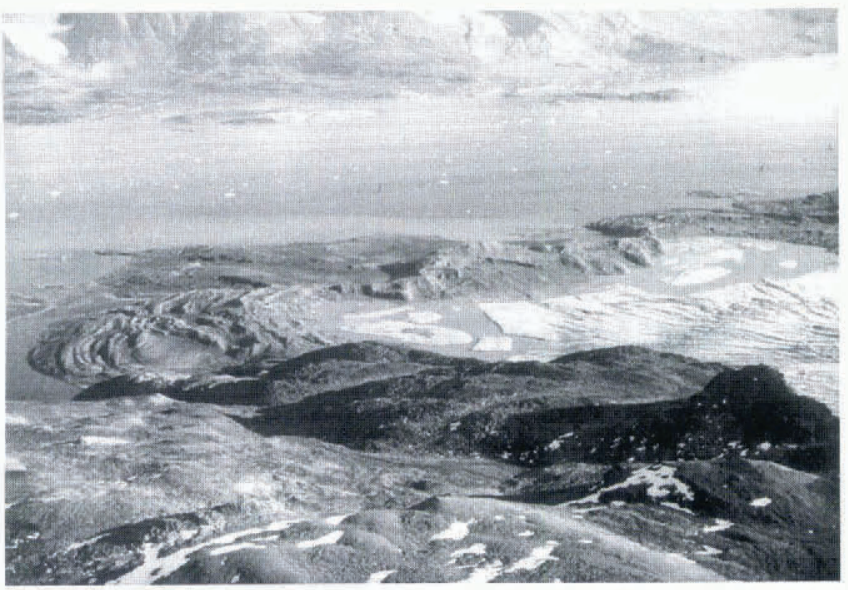

a

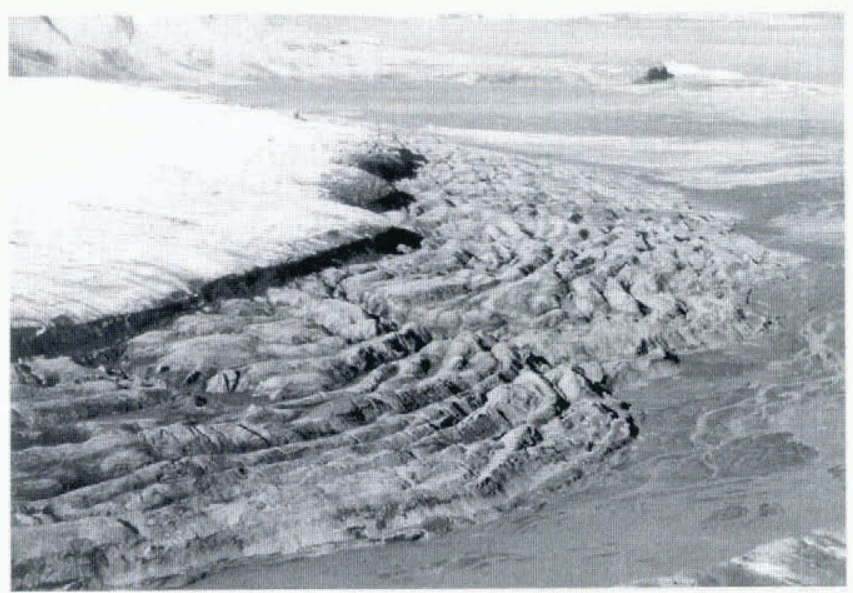

b

Fig. 1. (a) The ablation area and moraine area of Erikbreen. (b) The glacier-front area of Usherbreen.

\section{SETTING}

The glacier Usherbreen $\left(78^{\circ} 15^{\prime} \mathrm{N}, 18^{\circ} 40^{\prime} \mathrm{E}\right)$ is located on the east coast of Spitsbergen (Fig. 2), the largest island of the Svalbard archipelago. The nearest meteorological station is in Longyearbyen, where the mean annual air temperature is about $-6^{\circ} \mathrm{C}$ and precipitation is about $200 \mathrm{mma}^{-1}$. At Usherbreen, mean temperatures are assumed to be a little lower, and precipitation higher, than in Longyearbyen. The glacier Erikbreen $\left(79^{\circ} 40^{\prime} \mathrm{N}\right.$, $12^{\circ} 30^{\prime} \mathrm{E}$ ) is situated on the northern shore of Liefdefjorden, northern Spitsbergen (Fig. 2). In Ny-Ålesund, $\sim 100 \mathrm{~km}$ southwest of Liefdefjorden (Fig. 2), there is a permanent weather station, where the average annual air temperature is $-6^{\circ} \mathrm{C}$ and precipitation is normally below $400 \mathrm{~mm} \mathrm{a}^{-1}$. Svalbard is in the zone of continuous permafrost, and the permafrost varies between $100 \mathrm{~m}$ in coastal areas and more than $400 \mathrm{~m}$ in the central mountain areas (Liestol, 1977). The geology of the Usherbreen area is dominated by Trias layers of marine schist and some sandstone up to about $300 \mathrm{~m}$ a.s.l. Above this height there is some grey and black schist from Jura (Flood and others, 1971). Under Erikbreen, mainly Lower Devonian sandstones are found in the accumulation area, while massive dense marble and interbedded schists dominate in the ablation area (Hjelle and Lauritzen, 1982).

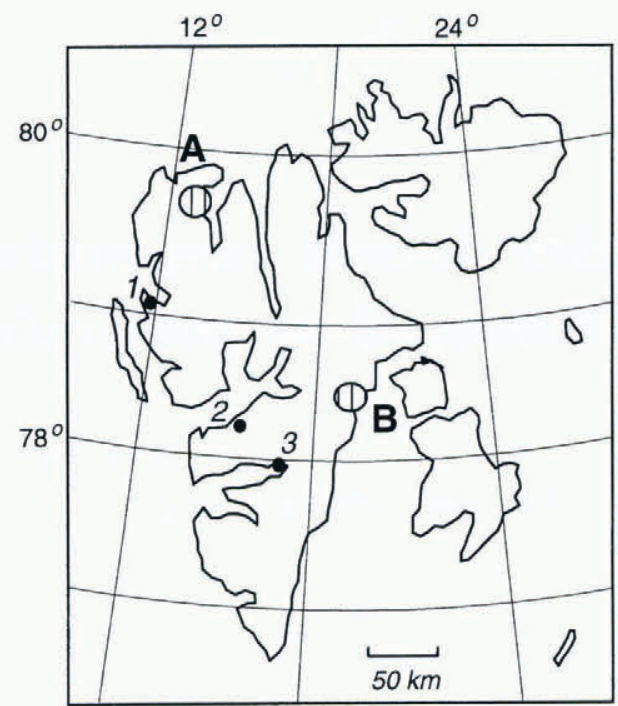

Fig. 2. Map of the Svalbard archipelago, showing the location of the Erikbreen (A) and the Usherbreen area (B). (1) Ny-Alesund, (2) Longyearbyen, (3) Svea.

\section{METHODS}

At Usherbreen the glacier-front velocities and the velocities of the moraine ridges in front of the glacier were measured by traditional surveying techniques using a theodolite and electronic distance meter (EDM) from fixed triangulation points to reflectors mounted on stakes. The sediment structure of the moraines of both Usherbreen and Erikbreen was recorded at several excavations. Soil samples were handled using conventional analysis techniques. At Erikbreen, probes of pore water were taken by lysimeters to measure the content of salt. The pore water was filtered (millipore $0.8 \mu \mathrm{m}$ ) and sampled in pre-cleaned plastic bottles. All pore-water samples were analyzed for major cations (AAS) and anions (chromatography). Mineralogical analyses were carried out on a Philips X-ray diffractor. Odegård and others (1992) and Etzelmüller and others (1993a) describe the methods used to record the thermal regime and glacier dynamics on Erikbreen.

\section{GLACIER DYNAMICS AND THERMAL REGIME}

Usherbreen surged in the period 1978-85. Before the surge the glacier had an area of $29 \mathrm{~km}^{2}$ and was $12 \mathrm{~km}$ long. The elevation ranged from 550 to $10 \mathrm{~m}$ a.s.l. The outwash plain was a few hundred metres from the fjord. Average slope was only $2.5^{\circ}$. In 1985 the glacier was surveyed and mapped (Hagen 1986, 1987; Fig. 3). It was observed from Landsat satellite images that the glacier front started to advance in 1978. Satellite images from 1980 show that the front had advanced about $1 \mathrm{~km}$, giving an annual motion of more than $300 \mathrm{~m}$. In the most active stage the velocity was probably considerably more than $1 \mathrm{~m} \mathrm{~d}^{-1}$. The glacier front moved more slowly in the following years, and during the summer of 1985 the surge was in its final stage. The front was then resting on a complex of arching moraine ridges formed during earlier surge advances. The glacier front was further out in 1985 


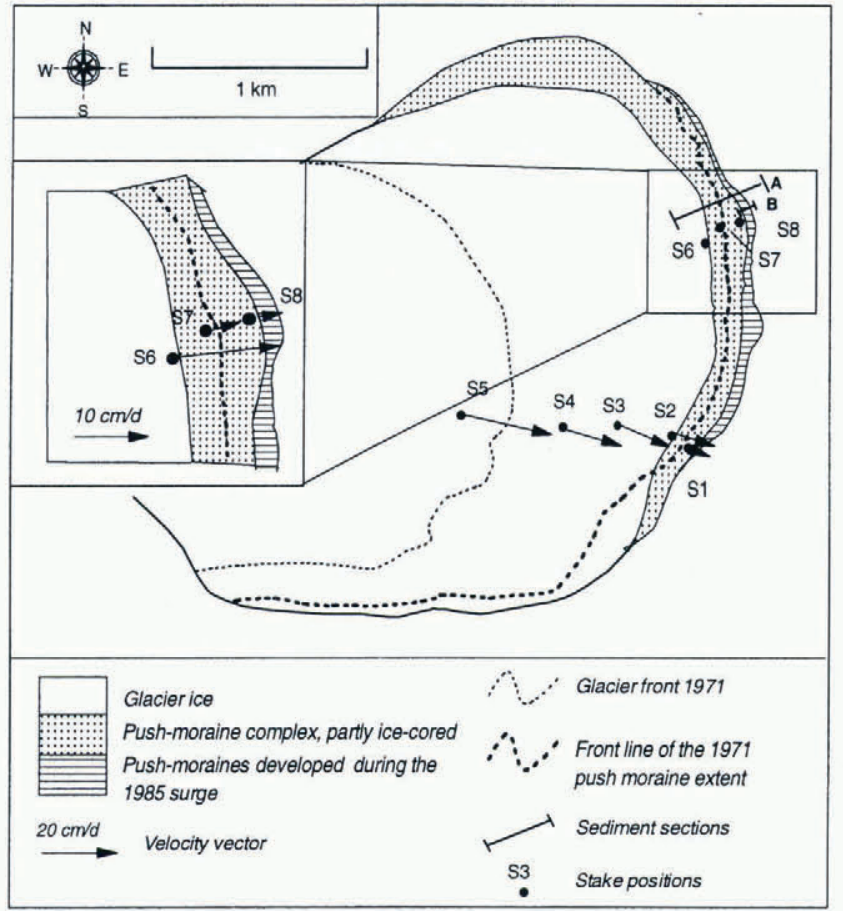

Fig. 3. Schematic map of the moraine area of Usherbreen and stake positions. The ridge system can be divided into distinct zones (shaded areas). $A$ and $B$ denote the location of the sediment sections in Figure 5.

than in any former surge, and it had moved over part of the old moraine ridges and on to fresh ground. The glacier had advanced a total of $1.6 \mathrm{~km}$ and covered an area of $4.5 \mathrm{~km}^{2}$. The total ice mass transferred to the lower part during the active surge phase was estimated to be $0.815 \mathrm{~km}^{3}$, about $20 \%$ of the total glacier volume.

Erikbreen was $9 \mathrm{~km}^{2}$ in area in 1990. The glacier is heavily crevassed in the ablation area. The altitudinal distribution of the glacier shows that a large part of the accumulation area is drained through a relatively narrow channel to the ablation area. Part of the glacier front calves into a lake dammed by ice-cored moraines. According to radio-echo sounding (Odegård and others, 1992) the maximum measured thickness on Erikbreen is nearly $300 \mathrm{~m}$, decreasing to $50 \mathrm{~m}$ close to the piedmontlike front. The average thickness is about $140 \mathrm{~m}$. Thermistor measurements and radio-echo sounding show that Erikbreen is polythermal, with a cold upper layer in the ablation area and in parts of the accumulation area. The cold layer represents $25-35 \%$ of the glacier thickness along the central flowline (Odegård and others, 1992). The ice beneath the cold surface layer is at the pressure-melting point (Fig. 4). The mean annual surface velocity ranged from 2 to $45 \mathrm{~m} \mathrm{a}^{-1}$. A clear difference between summer and winter velocities was observed. Field observations and theoretical calculations indicate high basal sliding velocities in the ablation area (Etzelmüller and others, 1993a; Fig. 4). Ice flow equal to a balance velocity appears to be maintained in a year with positive mass balance, so the glacier is probably not building up to a surge. This is also indicated by comparison of digital glacier surface maps based on air photos from 1938, 1970 and 1990 (Etzelmüller and others, 1993b; Etzelmüller 1995).

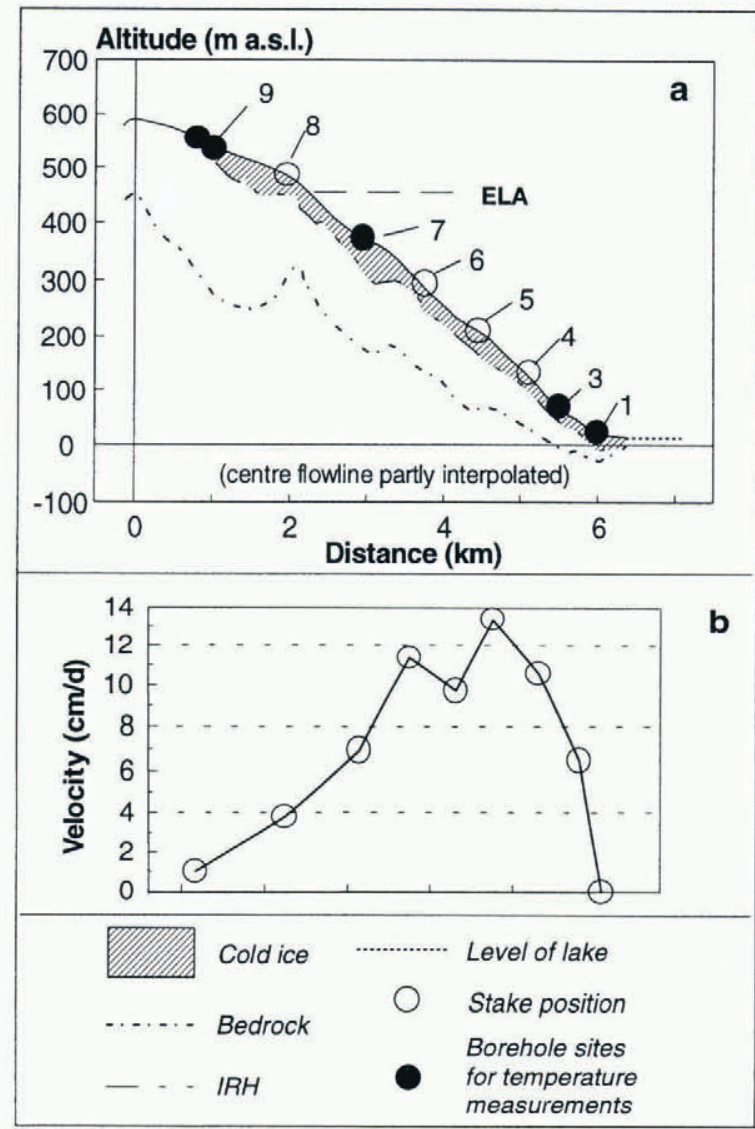

Fig. 4. (a) Thermal regime of Erikbreen, map based on low-frequency radio-echo sounding (Odegard and others, 1992). (b) Longitudinal velocity profile on Erikbreen, showing high velocities in the ablation area of the glacier.

\section{RESULTS}

\section{Usherbreen moraine dynamics and morphology}

The velocity of Usherbreen was measured in 1985 along two profiles (Fig. 3). The measurements showed that the velocity was still higher than if the glacier had been in the quiescent stage between two surges. The velocity increased from about $15.0 \mathrm{~cm} \mathrm{~d}^{-1}$ near the margin $(\mathrm{S} 2$ and S8) to about $30.0 \mathrm{~cm} \mathrm{~d}^{-1} 1.5 \mathrm{~km}$ up on the tongue (S5) (Table 1; Fig. 3).

The velocity observations confirmed that the ice in the old terminal ridges was reactivated. During the first year of the surge the glacier seems to have moved over the more than $1 \mathrm{~km}$ long, flat area proximal to the old moraine ridges without pushing up any material. The glacier advance was then hindered by the ridges. The whole ridge system was then reactivated and pushed forward. The glacier moved two to three times as fast as the ridges nearest the glacier front (see stakes $\mathrm{Sl}$ against $\mathrm{S} 2$, and S7 against S8 in Table 1 and Figure 3), and the glacier front therefore gradually advanced over the old ridges. The motion of the ridges decreased outwards from the glacier front. However, at S6, $230 \mathrm{~m}$ from the glacier front, the velocity was still $5 \mathrm{cmd}^{-1}$, and motion was observed at the surface of the sandur in front of the ridge system more than $300 \mathrm{~m}$ from the glacier. Small shear planes were formed there in the dry, few centimetres 
thick, surface clay layer. Parts of the ridge system were pushed $200 \mathrm{~m}$ forward during the surge (Fig. 3).

Only the old ridges nearest the glacier contained ice cores that were reactivated. The more distant ridges contained no pure ice but only folded sandur material (Fig. 5). The layers in the ridges had different thickness and consisted mainly of sorted material of different grain-size, in two main groups: (1) typical sandur conditions with pebbles, sand and silt, and (2) marine silt and clay layers (Fig. 5). The compressive flow results in deformation both in the old ridges and in formerly undisturbed frozen sediment layers on the sandur in front of the ridge system. Folding, thrust faulting and overriding all occur due to differential velocity of the ridges. The ridges usually had an asymmetric form with the steepest part downstream, often resulting in a small talus cone. The layers became gradually steeper towards the glacier, and close to the glacier dipped about $50^{\circ}$.
Deformed ice layers were observed in the newly folded ridges (Fig. 5b).

\section{Erikbreen moraine morphology and stratigraphy}

The moraine system at Erikbreen can be divided into three types (Fig. 6a):

(1) An outermost push-moraine system including three major moraine lobes.

(2) An arc of ice-cored moraines.

(3) An innermost flow-till area adjacent to the glacier lake.

The frontal ice-cored moraines end in an ice cliff towards the mud-flow area. Shear planes and material bands are frequently observed in the ice cliff, showing that

\begin{tabular}{|l|lll|}
\hline $\begin{array}{c}\text { Glacier } \\
\text { front }\end{array}$ & $\begin{array}{c}\text { Pre-1985 push-moraine ridges } \\
\text { moved by the 1985 surge }\end{array}$ \\
by the 1985 surge
\end{tabular}
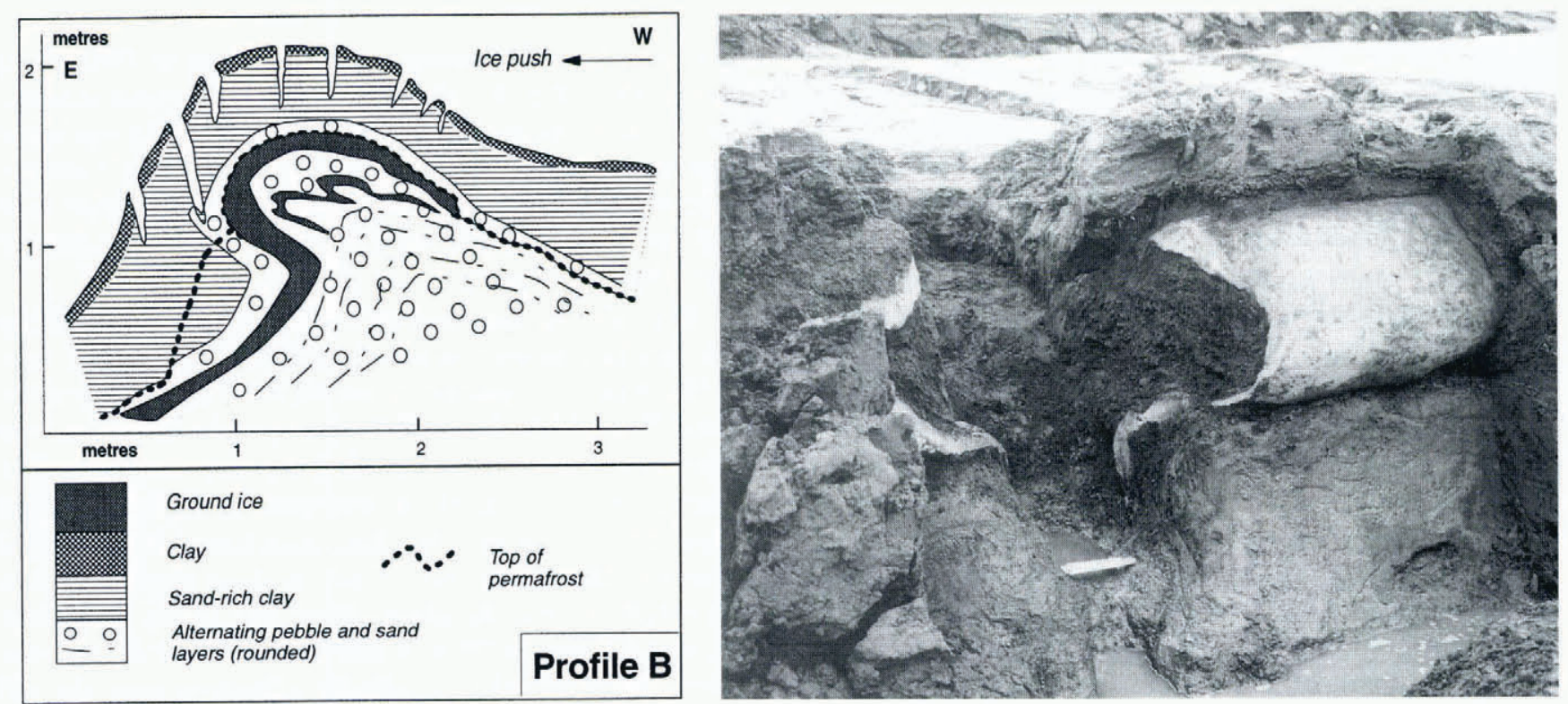

Fig. 5. Section logged in the push-moraine area of Usherbreen. The structure of the ridge system could be observed in a crosssection carved through the ridge system by a water channel (profile A). The sediment layers are highly dipped and deformed; folded ice layers are frequently observed. Profile B shows a recenlly developed push moraine, which is formed mostly in frictional sands and gravels. In connection to shear planes, ice lenses were often found. The photo of the ridge in profile B shows deformed ice layers. 
Table 1. Results of velocity measurements al Usherbreen in 1985. Slake positions S1, S6 and S7 were situated in the moraine area (cf. Fig. 3). Strain-rale values are average values from readings in the measurement periods. For the push-moraine area, an average shortening of $3.5 \mathrm{ma}^{\prime}$ $\left(1.0 \mathrm{~cm} \mathrm{~d}^{l}\right)$ between $S 6$ and $S 7$ was estimated in the postsurge period

\begin{tabular}{|c|c|c|c|c|c|}
\hline Profile 1 & S1 & $S 2$ & S3 & St & $S_{5}$ \\
\hline Distance to front (m) & -30 & 70 & 370 & 820 & 1470 \\
\hline \multicolumn{6}{|c|}{ Velocity $\left(\mathrm{cm} \mathrm{d}^{-1}\right)$ : } \\
\hline $15.08-16.08$ & 9.2 & 20.2 & 26.4 & 31.0 & 43.6 \\
\hline $16.08-23.08$ & 7.6 & 14.4 & 19.5 & 21.9 & 31.3 \\
\hline $23.08-27.08$ & 5.2 & 11.2 & 14.3 & 16.3 & 26.0 \\
\hline Profile 2 & S6 & $S 7$ & $S 8$ & & \\
\hline Distance to front (m) & 230 & 60 & -60 & & \\
\hline \multicolumn{6}{|l|}{ Velocity $\left(\mathrm{cm} \mathrm{d}^{-1}\right)$ : } \\
\hline $17.08-19.08$ & 5.2 & 6.3 & 17.8 & & \\
\hline $19.08-27.08$ & 4.9 & 6.0 & 17.9 & & \\
\hline
\end{tabular}

$\$ 2 / S 3 \quad S 6 / S 7 \quad S 7 / S 8 \quad S 1 / \$ 2$

\begin{tabular}{llllll}
\hline Strain rate $\left(\mathrm{a}^{-1}\right)$ & -0.05 & 0.02 & 0.3 & -0.4
\end{tabular}

it is of glacial origin. The moraine material above the ice cores is locally built of sand-rich glaciofluvial and glaciolimnic sediments. They are often disturbed and tilted, indicating ice advances and reactivation of the ice cores (Fig. 6b). Push moraines are concentrated in three lobes. Common to all three are internal sediment structures showing foliation and signs of stress failure. The surficial material in this area is dominated by marine deposits such as shell-bearing loamy silts, gravelly beach sediments and consolidated till layers (Fig. 6b).

Geotechnical work showed that the salt content in the pore water depresses the freezing point, leading to increased liquid water at sub-zero temperatures (cf. Tsytovich, 1975). The pore-water chemistry of the pushmoraine material was therefore analyzed. Pore-water chemistry of samples taken in the marine sediments differed from that of the lodgement till, even when the measurements were taken at adjacent sites. While the clay-rich marine sequences had a large amount of salt in the pores (mean $15 \mathrm{gl}^{-1}$ ), the pore water in the lodgement till contained a normal soil water solute of less than $1 \mathrm{gl}^{-1}$.

\section{DISCUSSION}

\section{Glacier debris input, transport and accumulation - the formation of ice-cored moraines}

The debris cover of the ice-cored moraines has two main origins: (1) supraglacial sedimentation on clean glacier ice, as observed on Erikbreen, and (2) melt-out of

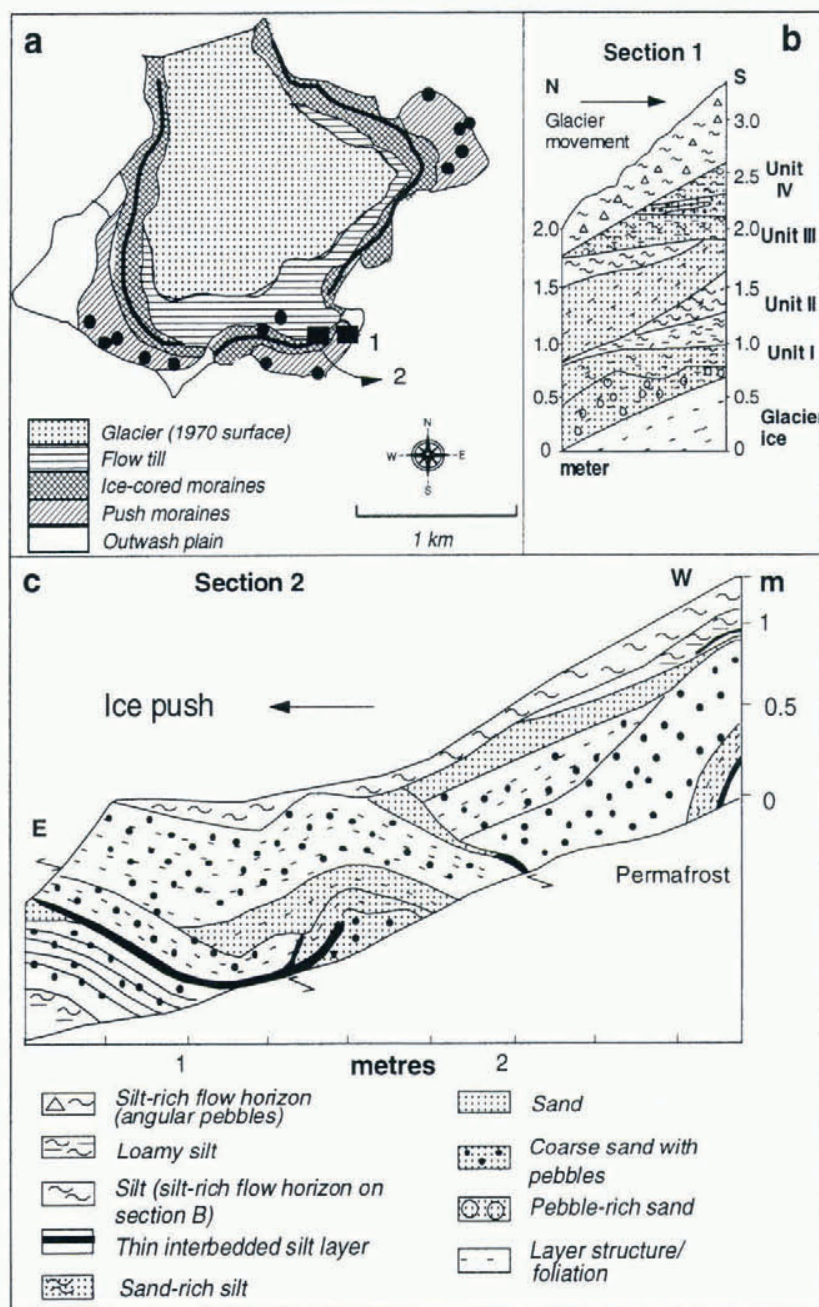

Fig. 6. (a) The moraine area of Erikbreen. The solid circles denote lysimeter sample sites, while the solid rectangles localise sections referred to in the text. (b) Example of a ice-cored moraine debris cover. Unit I shows foliated stratified sediments, varying between well-rounded glaciofluvial pebbles and sandy silts. Unil II consists of dipped stratified sands of glaciofluvial origin. Unit III shows horizontal stratified layers in sorted sandy silts. Unil IV is a flow horizon rich in pebbles, which can be recognised all over the moraine area as an upper layer. (c) Example from a push-moraine section. The section shows well-sorled glaciofluvial and glacio-marine sediments, which are folded and thrusted. Ice push from west to east.

englacial debris. The latter is connected to extraglacial material input in the accumulation area and subglacial input. Subglacial material input is governed mainly by two different processes, regelation and basal adfreezing of till (cf. Boulton 1970, 1972). The first process takes place under temperate ice with basal sliding conditions. On Erikbreen, high basal sliding values are suggested, and on Usherbreen the surge advance is mainly due to basal sliding. Thus, regelation processes are possible. However, regelation is connected to fine-grained debris (cf. Weertman, 1961), and cannot explain the material bands and even complete sediment layers observed on exposed glacier ice. The second process is closely connected to the temperature regime of the glaciers (cf. Boulton, 1972). Polythermal surging glaciers in 


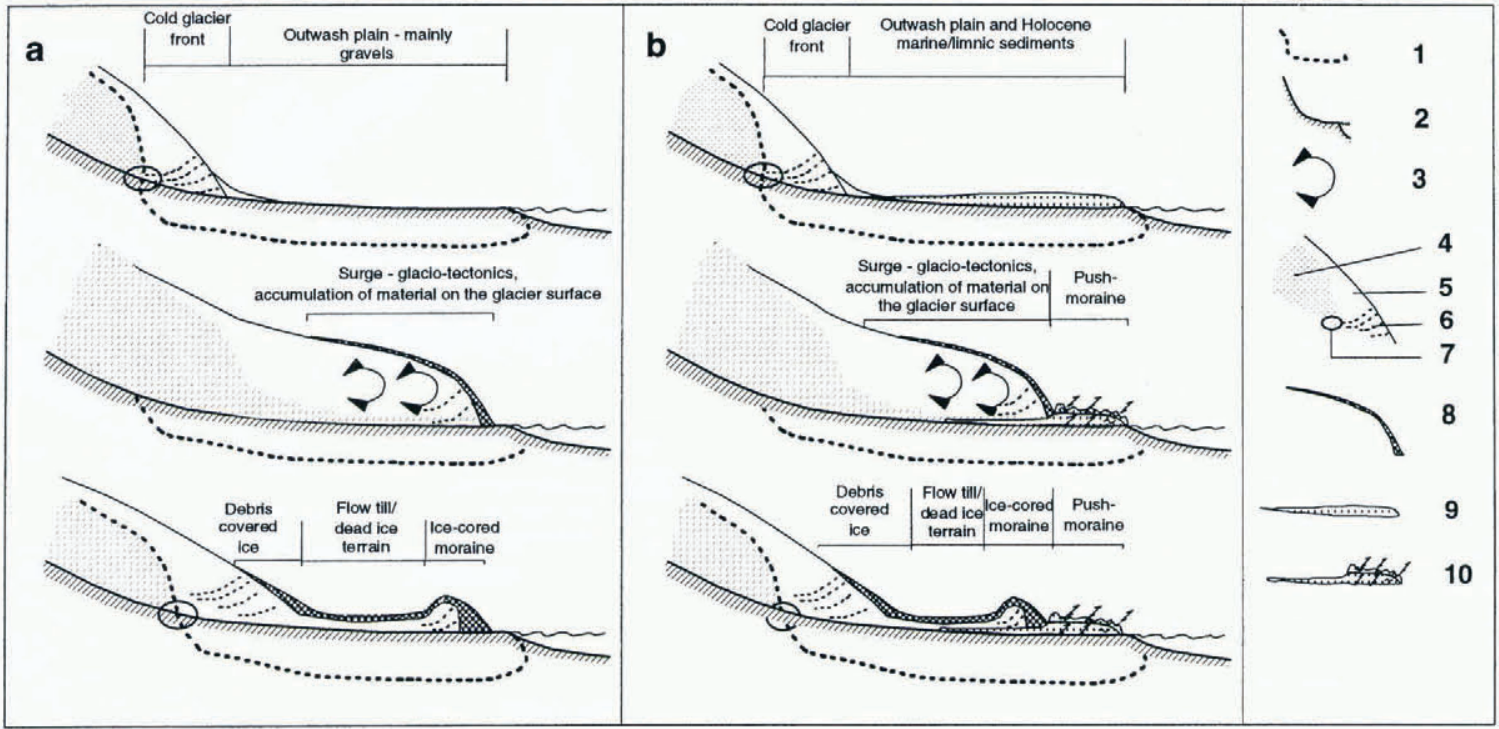

Fig. 7. (a) Schematic depiction of the formation of ice-cored moraines under the condition of a rapid advance/surge of the glacier over bedrock or frictional undeformable sediments. 1, Base of permafrost. 2, Bedrock. 3, Deformed ice during a surge, glacio-lectonical processes. 4, Temperate ice at the pressure-melting point. 5, Cold ice. 6, Shear zone and/or englacial material bands. 7, Transition zone between net melting and net freezing conditions according to Boulton (1972). In this zone, on-freezing of subglacial sediments may lake place. Transport of material towards the surface. 8, Debris-covered glacier front, material cover preserving underlying glacier ice. (b) The same as (a), but now the glacier advances over a frozen, fine-grained sediment layer. This causes deformation of the sediments. 9, Frozen marine/limnic sediment layer. 10, Deformed sediment layers, push-moraines, with thrusts, plastic deformation/foliation of sediments. In both cases lakes may be developed between the ice-cored moraine ridge and the glacier front, causing sedimentation of lacustrine sediments in this area. The ice-cored moraine ridge shows the maximum extent of the glacier advance.

Svalbard have cold marginal zones in the quiescent phase due to permafrost conditions, and thus low mass flux (cf. Lefauconnier and Hagen, 1991). It is only during surges that the glaciers slide and the base is at the melting point. The cold marginal zones cause the glacier fronts to be frozen to the ground, preventing basal sliding motion. Material transported in the transition between the cold marginal bed zone and the temperate bed zone is then restricted to englacial or supraglacial transport, upwards relative to the glacier surface, as discussed by Goldthwait (1951), Weertman (1961) and Boulton (1972). On both Erikbreen and Usherbreen freezing-on of subglacial sediments can therefore be assumed. Dye-tracer and suspensiontransport studies and direct observations on Erikbreen indicate the existence of a basal till layer (Vatne and others, 1995).

The abundance of ice-cored moraines shows a typical accumulation pattern of glacial material. Normally, one or two well-developed arcs of moraines are observed, followed by a dead-ice terrain with melt-out tills and flow tills. The rim of ice-cored moraines then denotes the maximum glacier advance. Thus, the genesis of these moraines is connected to very active phases, with rapid advances and high material transport. After an active phase the glacier remains in the same position for a long period, melting down. Hence, englacial material is transported and accumulated at the surface until permafrost conditions prevent further melting (Fig. 7). This proposed formation of the ice-cored moraines requires rapid glacier advances with long-lasting retreat phases under permafrost conditions.

\section{Deformation of proglacial sediments - the formation of push moraines}

To investigate whether it is possible for a glacier to deform proglacial sediments, critical values were estimated for the strength of the sediment and the forces transmitted from the glacier to the sediment. We can assume sediment deformation if the transmitted stress from a glacier $\left(\sigma_{\mathrm{gl}}\right)$ exceeds the sediment creep strength or yield stress $\left(\sigma_{\text {sed }}\right)$, at least locally and temporarily.

For estimating the applied stress from a glacier two scenarios are considered. In the first, the glacier is assumed to have advanced over a layer of frozen sediments resting on top of unfrozen deformable sediments with insignificant bonding between the frozen and unfrozen sediments (Fig. 8a). The applied stress from the glacier $\left(\sigma_{\mathrm{gl}}\right)$ is here a function of the subglacial shear stress $\left(\tau_{\mathrm{b}}\right)$ on the sediments and the relation between the length $(s)$ of glacier advance over the deformable sediments and the sediment thickness $(h)$. The total transmitted horizontal stress $\left(\sigma_{\mathrm{gl}}\right)$ on the sediments can then be estimated after $\sigma_{\mathrm{gl}}=\tau_{\mathrm{b}} s / h$ (Schindler and others, 1978). The second scenario is the rapid advance of the glacier and push towards an older icecored moraine ridge as observed at Usherbreen (Fig. 8b). In this case one has to consider the deformation of ice when the ice hits the moraine ridges. The deformation depends on glacier velocity, ablation and ice temperature. Because of the deformability of the ice, lower stress values are expected to be transmitted to the sediment compared to the first scenario. Based on Glen's (1955) flow law the stress to the sediments $\left(\sigma_{\mathrm{gl}}\right)$ was estimated by using the situation for uniaxial compression, confined in one direction (cf. 


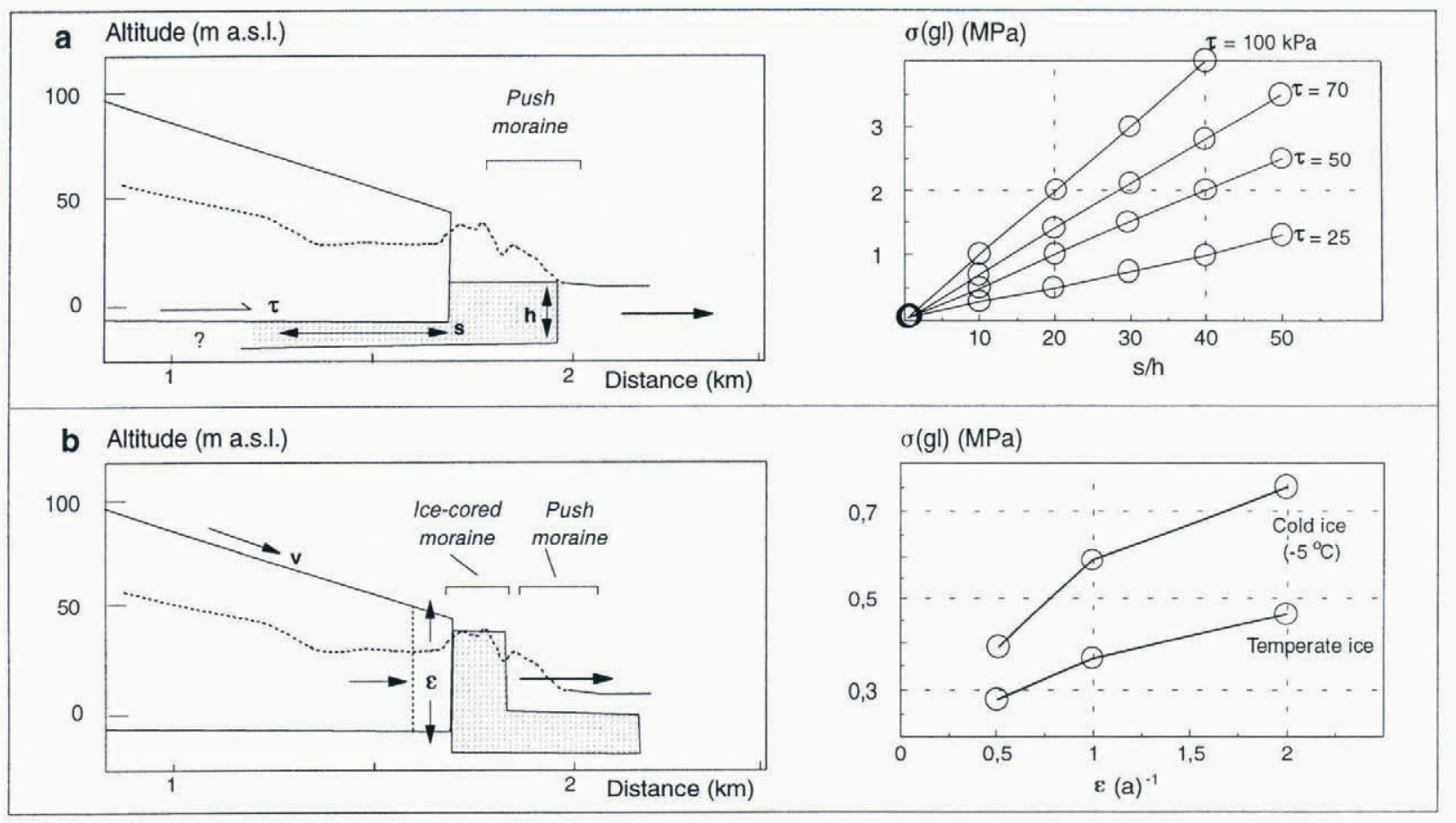

Fig. 8. (a) Lefthand diagram shows a schematic draft which was used to estimate values of the glacier-induced stress to the subglacial sediments $\left(\sigma_{\mathrm{gl}}\right)$ when the glacier has advanced over deformable sediments (Schindler and others, 1978). Here s is the distance of the glacier advance over the sediments, $h$ is sediment thickness and $\tau$ is basal shear stress. Righthand diagram shows the relation between $s / h$, shear stress $(\tau)$ and transmitted horizontal stress $\left(\sigma_{\mathrm{gl}}\right)$ on the glacier. (b) Lefthand diagram shows a draft of the situation where the advancing glacier front pushes against a pre-existing ice-cored moraine ( $v$ is glacier velocity, $\varepsilon$ is strain). Righthand diagram shows the stress to the sediments $\left(\sigma_{\mathrm{g} 1}\right)$ estimated by using the situation for uniaxial compression for cold and temperale ice (see lext).

Paterson, 1994): $\sigma_{\mathrm{gl}}=2\left(\varepsilon_{x} / A\right)^{1 / n}$ where $A$ and $n$ are flowlaw constants and $\varepsilon_{r}$ is the strain rate in flow direction per year. $A$ depends on the ice temperature, and $\sigma_{\mathrm{gl}}$ increases with decreasing $A$ values (Fig $8 \mathrm{~b}$, right diagram).

The creep strength of sediment in a permafrost environment is, in contrast to that of unfrozen sediment, strongly dependent on liquid-water content, ice content and the duration of applied stress (cf. Tsytovich, 1975; Williams and Smith, 1989). Liquid-water content and ice-content are in turn dependent on sediment type and sub-zero temperatures. Fine-grained sediment contains more liquid water than coarse-grained sediment at the same temperature. In areas with marine sediments, the free water content is in addition dependent on salt content of the pore water, which depresses the freezing point considerably (cf. Tsytovich, 1975; Ogata and others, 1982). Hence, the Mohr-Coloumb failure criterion takes the following form:

$$
\tau_{t, s, T}=c_{t, s, T}+\sigma^{\prime} \tan \theta
$$

where shear strength $\tau$ and cohesion $c$ are functions of temperature $T$, pore-water salinity $s$ and $\operatorname{time} t, \tan \theta$ is the angle of internal friction, and $\sigma^{\prime}$ is the effective normal stress. This equation states that cohesion is the dominant factor controlling shear strength at sub-zero temperatures. This being due to the fact that the ice-water equilibrium in the soil pores reacts at varying temperatures and applied stress, leads to ice flow within the soil and deformation of solid-ice interfaces (Williams and Smith, 1989).
Coarse, frictional sediments have no cohesion in unfrozen state. The strength characteristics are due to the normal pressure which governs the frictional forces between single sediment grains. When frozen, ice bonds between grains result in a considerable cohesion component, and sediment strength increases. Unsaturated frozen sands or gravels can have strength characteristics comparable to sandstones, and deformation will occur in the ice rather than in the sediment. If there is a high porewater content, all pores in the sediment can be filled with ice when frozen, and the contact between pebbles can be partly replaced by ice bonds (Tsytovich, 1975; Johnston, 1981 . Friction is then reduced and the creep characteristics of ice determine the sediment strength. As ice has a very low long-term shear strength, layers of supersaturated gravelly sediments are plastically deformable under sub-zero temperatures. Plastic deformation of gravelly sediments therefore requires at least seasonal sub-zero temperatures. Kälin (1971) treated the gravelly push moraines in front of Thompson Glacier, Arctic Canada, as a sliding mass, and calculated maximum values for cohesion and angle of internal friction as $c=0.13 \mathrm{MPa}$ and $\theta=5^{\circ}$. These values are obtained when most of the internal friction between the solids can be neglected due to locally high ice content.

Fine-grained, cohesive sediments have lower angles of internal friction and considerable cohesion. In unfrozen state, shear strength is low and depends on the porewater pressure Equation (1)), and sediments can be deformed over a smaller range. When frozen, ice bonds increase the cohesion, and sediment strength increases. 
The sediment then acts more like a compact mass, allowing transfer of stresses over long distances. However, in fine-grained sediments water remains unfrozen at sub-zero temperatures, which weakens the sediment. Tsytovich (1975) distinguishes between weak permafrost, which is plastically deformable, and hard permafrost, where the climate and lithology create non-deformable sediment conditions.

On Erikbreen and Usherbreen, both cohesive and frictional sediments were deformed (Figs 5 and 6). The marine sediments in the Erikbreen glacier forefield can be considered as clayey loams containing gravels. Such sediments normally show strength values well below 1.0 MPa (cf. Tsytovich, 1975). When considering the temperature and saline conditions as measured in several places at Erikbreen, values below $0.2 \mathrm{MPa}$ are realistic. Marine sediment thicknesses vary locally, and are on the order of $10 \mathrm{~m}$. At its maximum extent, Erikbreen had advanced at least $200-300 \mathrm{~m}$ over soft sediments. Basal shear stress values were then calculated to be about $50 \mathrm{kPa}$ in the frontal area. For the first scenario (Fig. 8a), values of $\sigma_{\mathrm{gl}}$ on the order of $1-1.5 \mathrm{MPa}$ were estimated, which will deform most fine-grained sediments with a considerable unfrozen water content. Lower basal shear stresses will produce high enough stresses only in thinner sediment layers (Fig. 8a).

Where the glacier pushes against already existing icecored moraines (Fig. 8b), values of $\sigma_{\mathrm{gl}}<0.3 \mathrm{MPa}$ are realistic, assuming a strain rate of $\varepsilon<0.3 \mathrm{a}^{-1}$ and cold ice. This strain rate is similar to the measured strain rate at Usherbreen (Table 1; Hagen, 1987). The outermost pushmoraine ridges at Erikbreen would probably deform during applied stresses of this order, assuming weak cohesive sediments or material supersaturated with clean ice. Permafrost conditions are, however, required.

On Usherbreen, the observed push-moraine formation started when the glacier hit the older ice-cored moraines. The direct measurements made it possible to estimate the stresses from the glacier, using the second scenario (Fig. 8b). With a measured maximum strain rate in the transition area between glacier front and moraine of $0.5 \mathrm{a}^{-1}$ in the post-surge period (Table 1) and a cold glacier front, stress values of $\sigma_{\mathrm{gl}} \sim 0.4 \mathrm{MPa}$ are estimated. Deformation is mainly seen in frictional fluvial sediments in the Usherbreen glacier forefield. This indicates local supersaturation of parts of the sediment with ice, or a clean-ice layer where sliding occurs under permafrost conditions.

These considerations raise the question whether the first surge advance of the glacier may have developed the largest forms, with only minor changes taking place since the development of the ice-cored moraines because of lower stress values transmitted to the proglacial sediments. It is debatable which of these two processes is responsible for sediment deformation. Kälin (1971) revealed strain rates on the glacier front close to $0.03 \mathrm{a}^{-1}$ which is the same order of magnitude as measured on Usherbreen (Table 1). Average compressive strain was $-0.02 \mathrm{a}^{-1}$ within the push moraine at Thompson Glacier, considerably higher than was measured at Usherbreen during the final stage of the surge. However, the difference between glacier velocity and ridge velocity was more enhanced on Usherbreen than on Thompson Glacier. It is suggested that the magnitude of glacier-front deformation due to an advance plays a minor role but may trigger the deformation process.

\section{Distributional pattern of push moraines on Svalbard}

The distribution of push moraines on Svalbard shows a clear pattern (Fig. 9). The forms are (1) all found below the Holocene marine limit and (2) most frequently found in areas of sedimentary bedrock. The unfrozen water content in the sediments governs their deformability under permafrost conditions, which in turn is dependent on pore-water salinity. This explains localisation according to point (1). In frictional sediments, ice-rich horizons work as sliding planes and deformation zones. Croot (1988b) claimed that ice is not necessary to explain pushmoraine forms in Iceland and that high pore-water pressure will cause decollation of sediments and then thrusting. He suggested that the availability of meltwater which reduces sediment strength and of near-surface ground-water is crucial for the formation of push moraines. On Svalbard, the permafrost condition prevents the water draining into the ground. The active-layer thickness is normally less than $1 \mathrm{~m}$, and the observed deformation structures at Erikbreen and Usherbreen clearly propagate into permafrost. In addition the active layer remains melted for only $2-3$ months during the summer.

Dependence of the formation of moraines on the bedrock geology is suggested to be due to periglacial frost weathering and glacier erosion. Frost weathering and glacier erosion produce fine-grained debris in areas dominated by clastic bedrock and high material input to the marine environment. This favours increased accumulation of fine-grained sediments in the shore area.

Several authors have claimed that the formation of push moraines in Svalbard is connected to the surge behaviour of the glaciers (cf. Croot, 1988a; Lefauconnier and Hagen, 1991). According to the above considerations, this means that rapid glacier advance over sediments over a large area is needed to produce sediment deformation. However, push moraines in other areas are built without surging glaciers. For example, Thompson Glacier in Arctic Canada built up push moraines during an advance spanning 10 years at average velocities of less than $20 \mathrm{ma}^{-1}$ Kälin, 1971). Rapid, non-surge advances should have a comparable effect on the marginal area of Svalbard glaciers. This would explain the push moraines at Erikbreen, which does not seem to be a surge-type glacier.

\section{CONGLUSIONS}

The formation and preservation of ice-cored moraines on Svalbard is related to cold glacier-front margins directly connected to permafrost conditions. Debris accumulation is due to supraglacial sedimentation or melt-out of englacial debris. Ice-cored moraine development is favoured by rapid advances and long retreat phases. 


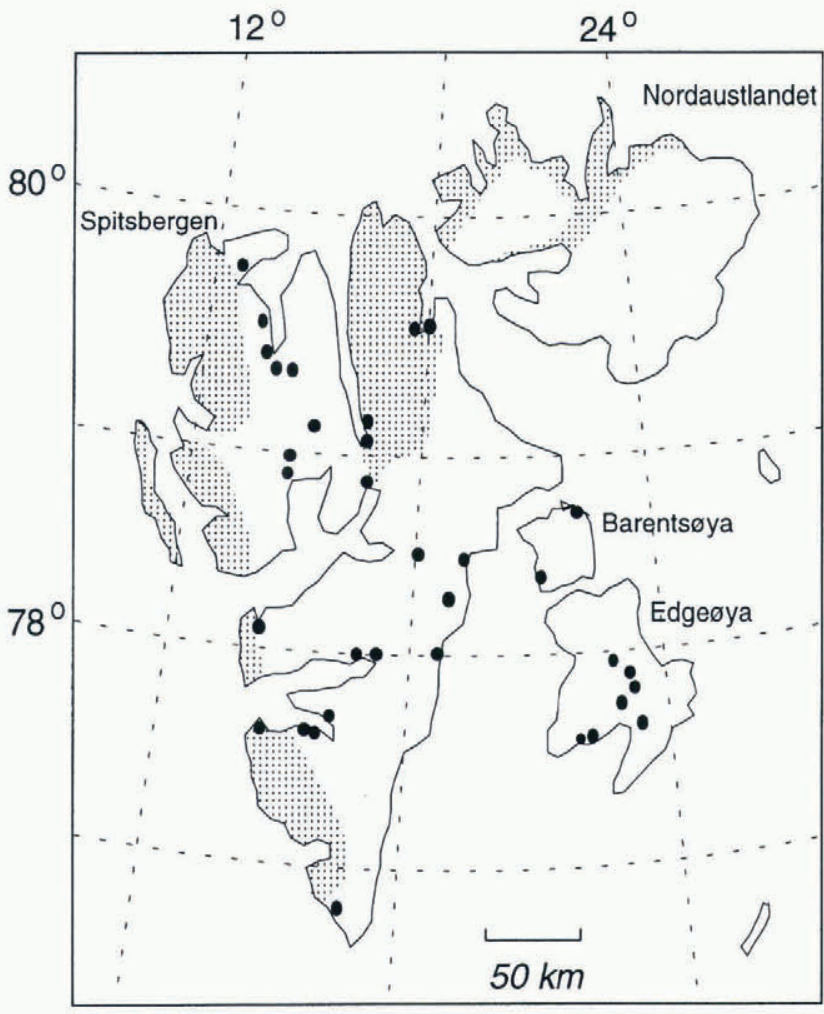

Fig. 9. Distribution of push moraines on the Svalbard archipelago, based on air-photo interpretation (scale 1:50000 and 1:15000). Only push moraines in the sense described in the text are registered. Push-moraine forms can easily be recognised and distinguished from icecored moraines by their regular ridge pattern. Most moraines are connected to morphologically sofler rock types (clastic sediments, shales, etc.). All registered push moraines are situated below the Holocene marine limit. In areas with thick surficial material cover, push moraines are more frequent (e.g. on Edgeoya). The shaded area displays the areas of melamorphic pre-Devonian bedrock on Spitsbergen.

The main factor controlling the formation of push moraines is the soil mechanics of the sediments which are strongly influenced by permafrost conditions. The unfrozen water content of the sediments governs deformability, which in turn depends on pore-water salinity. At Usherbreen, the compressive flow under a glacier advance results in reactivation of old ridges and in formerly undisturbed frozen sediment layers on the sandur in front of the ridge system. Thus, folding, thrust faulting and overriding all occur. The surge behaviour of the glaciers accelerates the development, but may not be the only cause. It is suggested that the push moraines at Usherbreen and Erikbreen are not strictly glacier forms but periglacial forms. Push moraines on Svalbard are deformed and disturbed sediments in permafrost where the stress applied is of glacial origin.

\section{ACKNOWLEDGEMENTS}

The studies at Erikbreen, where B. Etzelmüller participated, were part of the interdisciplinary German-led project "Stofftransporte Land-Meer in polaren Geosystemen", with participating researchers from Germany, Switzerland and Norway. The project was co-ordinated by Professor W.D. Blümel, University of Stuttgart, Germany. The Norwegian group was led by Professor J. L. Sollid. Professor emeritus O. Liestol gave constructive advice to this group. P. H. Bo, L. Langkaas and I. Berthling took part in the field-work. The authors received financial support from the Deutsche Forschungsgemeinschaft (DFG), Norsk Hydro A/S and the Polar Committee of the University of Oslo. The Norwegian Coast Guard helped with equipment and personnel transportation. All laboratory work was carried out at the Department of Geology, University of Oslo. The studies at Usherbreen were initiated by O. Liestol, mainly conducted by J. O. Hagen and financed by a scholarship from the Norsk Polarinstitutt. N. Flakstad participated in both the field-work and the preparation of field data. T. Fergus and L. Lindberget corrected the English. The authors wish to thank all contributing persons and institutions.

\section{REFERENCES}

Boulton, G.S. 1970. On the origin and transport of englacial debris in Svalbard glaciers. J. Glaciol., 9 56), 213229.

Boulton, G. S. 1972. The role of thermal régime in glacial sedimentation. In Price, R.J. and D. E. Sugden, comps. Polar geomorphology. London, Institute of British Geographers, 1-19. (Special Publication 4.

Croot, D. G. 1988a. Glaciotectonics and surging glaciers: a correlation based on Vestspitsbergen, Svalbard, Norway. In Croot, D. G.. ed. Glaciotectonics: forms and processes. Rotterdam, A. A. Balkema, 49-61.

Croot, D. G. 1988b. Morphological, structural and mechanical analysis of neoglacial ice-pushed ridges in Iceland. In Croot, D. G., ed. Glaciotectonics: forms and processes. Rotterdam, A. A. Balkema, 3348.

Etzelmüller, B. 1995. Geomorphometrical and geomorphological studies of selected polythermal glaciers in a permafiost environment on Spitsbergen, Svalbard. Univ. Oslo Rapp. Naturgeogr. 4.

Eıcelmüller, B., G. Vatne, R.S. Odegård and J. L. Sollid. 1993a. Dynamics of two subpolar valley glaciers - Erikbreen and Hannabreen, Liefdefjorden, northern Spitsbergen. Geogr. Ann., 75A 1-2), $41-54$.

Etzelmüller, B., G. Vatne, R. S. Odegård and J. L. Sollid. 1993b. Mass balance and changes of surface slope, crevasse and flow patterns of Erikbreen, northern Spitsbergen: an application of a geographical information system (GIS). Polar Res., 12 2), 131-146.

Flood, B., J. Nagy and T. Winsnes. 1971. Geological map, Svalbard, 1:500,000 Sheet IG. Spitsbergen, southern part. Yor. Polarinst. Skr. $154 \mathrm{~A}$.

Glen, J. W. 1955. The creep of polycrystalline ice. Proc. R. Soc. London. Ser. A, $228+1175$ - 519-538.

Goldthwait, R. P. 1951. Development of end moraines in east-central Baffin Island. J. Geol., 596 , $567-577$.

Gripp, K. 1929. Glaziologische und geologische Ergebnisse der Hamburgischen-Spitzbergen Expedition 1927. Abh. Valurwiss. Vereins Hamburg, 22 2 4), 145-249.

Hagen, J. O. 1986. Glasiale prosesser ved utvalgte breer: subglasiale undersokelser ved Bondhusbreen, Folgefonni. Surgestudier ved Usherbreen, Svalbard. Geogr. Inst. Medd. Nalurgeogr. Ser. 4.

Hagen, J. O. 1987. Glacier surge at Usherbreen, Svalbard. Polar Res., $52,239-252$.

Hjelle, A. and O. Lauritzen. 1982. Geological map, Svalbard, 1:500,000. Sheet 3G. Spitsbergen, northern part. Nor. Polarinst. Skr, $154 \mathrm{C}$.

Johnston, G.H., ed. 1981. Permafrost: engineering design and construction. New York, John Wiley and Sons.

Kälin, M. 1971. The active push moraine of the Thompson Glacier, Axel Heiberg Island. Canadian Arctic Archipelago. Canada. Montréal. McGill University. (Axel Heiberg Island Research Reports. Glaciology 4. )

Lefauconnier, B. and J. O. Hagen. 1991. Surging and calving glaciers in eastern Svalbard. Nor. Polarinst. Medd. 116. 
Liestol, O. 1969. Glacier surges in west Spitsbergen. Can. f. Earth Sci., 6 4), Part 2, 895-897.

Liestol, O. 1977. Pingos, springs and permafrost in Spitsbergen. Nor. Polarinst. Árbok 1975, 729.

Odegård, R. S., S. -E. Hamran, P. H. Bo, B. Etzelmüller, G. Vatne and J.L. Sollid. 1992. Thermal regime of a valley glacier, Erikbreen, northern Spitsbergen. Polar Res., 11 2), 69-79.

Ogata, N., M. Yasuda and T. Kataoka. 1982. Salt concentration effects on strength of frozen soils. In Proceedings of the Third International Symposium on Ground Freezing, 22 24. June 1982, Hanover, New Hampshire. Hanover, NH, U.S. Army Corps of Engineers. Cold Regions Research and Engineering Laboratory, 3-10.

Paterson, W. S. B. 1994. The physics of glaciers. Third edition. Oxford, etc,, Elsevier Science Ltd.

Schindler, C., H. Röthlisberger and M. Gyger. 1978. Glaziale
Stauchungen in den Niederterrassen-Schottern des Aadorfer Feldes und ihre Deutung. Eclogae Geol. Helv., 71 1), 159-174.

Sollid, J. L. and L. Sorbel. 1988. Influence of temperature conditions in formation of end moraines in Fennoscandia and Svalbard. Boreas, 17 (4), 5.53-5.58.

Tsytovich, N.A. 1975. The mechanics of frozen ground. Washington, DC, McGraw-Hill Book Company.

Vatne, G., B. Etzelmüller, R.S. Odegård and J.L. Sollid. 1995. Hydrology of a polythermal glacier, Erikbreen, northern Spitsbergen. Nord. Hydrol., 26 4), 16990.

Weertman, J. 1961. Mechanism for the formation of inner moraines found near the edge of cold ice caps and ice sheets. f. Glaciol., 3 (30), 965978.

Williams, P.J. and M. W. Smith. 1989. The frozen earth: fundamentals of geocryology. Cambridge, Cambridge University Press. 